\title{
A proposal for empowering slum dwellers as a viable way of addressing urbanization challenges in Katanga slum, Kampala, Uganda
}

\author{
Godfrey Omulo $^{1^{\dagger}}$, Musinguzi Muhsin ${ }^{2}$, Ismail Kasana ${ }^{2}$, Resty Nabaterega ${ }^{1}$ \\ ${ }^{1}$ Department of Agricultural and Bio-systems Engineering, Makerere University, Kampala 7062, Uganda \\ ${ }^{2}$ Department of Human Nutrition, Makerere University, Kampala 7062, Uganda
}

\begin{abstract}
Slum settlement, a direct result of the rapid worldwide urbanization is a common site in most developing countries. Uganda is among the top African countries with high number of slums. The status of Katanga slum located in the low-lands between Mulago national hospital and Makerere University is a typical of many other slums within Uganda. This project proposal seeks to tackle urbanization challenges by specializing in slum upgrading as a sustainable way of curbing the menace. An integrated toilet, biogas, poultry and backyard gardening project is proposed as a channel of boosting the Katanga slum dwellers' economic, sanitation and domestic energy status. Designed to serve up to 30 households, the project will utilize residual wastes from poultry houses and toilets to produce biogas and slurry. The biogas yield will provide clean cooking fuel and energy for lighting, while the slurry used as organic fertilizers to improve vegetable yields. The social, economic and environmental impacts of the project will empower the vulnerable women and children within the slums and reduce water pollution and land degradation. This affordable project can be applied in developing countries experiencing slum settlement challenges as a strategy for reducing urbanization pressure.
\end{abstract}

Keywords: Backyard gardening, Biogas, Energy status, Pollution, Slum, Urbanization

\section{Introduction}

Urbanization is a transformational change from rural to urban civilization. Africa and Asia continents are urbanizing more rapidly than other regions of the world [1]. Currently, 54\% of the world's population live in urban areas, a proportion expected to increase to $68 \%$ by 2050 [1]. Urbanization brings overcrowding, social, health and pollution challenges. High crime incidences, discrimination, violence, poverty, children and women exploitation are characteristics of slum dwelling.

The average annual urbanization rate is highest in Asia (1.5\%) and Africa (1.1\%) though the trends are slowing down as regions become more modernized [1]. In urban and urbanising areas, industrial development impacts the living standards, economic and scientific growth as well as socio-cultural and technological advancement [2]. In Africa, living standards are changing with increased commodity costs. The major causes of urbanization in
Africa are rural-urban migration and urban biased development strategies that have translated to local, national and regional armed conflicts. According to UN, Department of Economic and Social Affairs, Population Division [1], rapid urbanization in developing countries calls for major changes in the way in which urban development is designed and managed.

Uganda is among the sixteen countries worldwide with high urbanization rates of about $20 \%$ [1] and a population growth rate of $3.3 \%$ [3]. Kampala city has a population of about 1.5 million and constitutes $25 \%$ of the country's total urban population [3]. Generally, urban population represents 18\% (6 million) of Uganda's total population of which $60 \%$ live in slums and informal settlements. This rapid urbanization due to the prevailing political stability is faced with many challenges related to food insecurity, sanitation, health, security, education, pollution and housing [4].

The Uganda National Slum Upgrading Strategy (UNSUS) under the ministry of lands, housing and urban development in collabo-
This is an Open Access article distributed under the terms of the Creative Commons Attribution Non-Commercial License (http://creativecommons.org/licenses/by-nc/3.0/) which permits unrestricted non-commercial use, distribution, and reproduction in any medium, provided the original work is properly cited.
Received January 31, 2017 Accepted June 6, 2017

${ }^{\dagger}$ Corresponding author

Email: omuloh@gmail.com

Tel: +254-723-215-608

Copyright (C) 2017 Korean Society of Environmental Engineers 
ration with UN Development Program has proposed several guidelines on slums upgrading. This project highlights strategies for slum residents' inclusion and participation as active partners in offering solutions to their prevailing conditions [5]. Therefore, an affordable and sustainable project utilizing available wastes resources and little investment is recommended. An integrated poultry farming cum biogas digestion plant utilizing wastes from poultry and toilets to yield biogas for domestic use is proposed. The resultant slurry are to be used as fertilizers in backyard gardens.

According to Zuzhang [6], biogas projects have social, economic and environmental impacts on vulnerable people in society. Again, according to Bill and Melinda Gates [7], chicken was seen as a money generating project that can create much income for the rural and urban poor. Similarly, backyard gardening has direct correlation with social and economic wellbeing of urban slum dwellers [8]. This project is aimed at improving the livelihood of Katanga slum dwellers by empowering them on the use of sustainable renewable energy and improved agriculture.

\section{Status of Katanga Slum}

Katanga is one of the biggest urban slums in Kampala city, Uganda. It is located in the valley between Mulago Hospital and Makerere University. It is a flood plain with a bigger area under wetland and swamps. It stretches about $1.5 \mathrm{~km}^{2}$ from Wandegeya to Kubiri and is divided into two administrative Local Council 1 zones; "Busia" and "Kimwanyi" (Fig. 1) [9]. The population of Katanga slum is over 20,000 people with more than $50 \%$ being children below 14 years. About $60 \%$ of the population occupy semi-permanent and temporary structures due to extreme poverty and $23 \%$ own houses while $77 \%$ are tenants [10]. Electricity is limited in the slum with only $4.3 \%$ of households utilizing it for lighting otherwise, about $84.2 \%$ and $12.1 \%$ use charcoal and firewood respectively for cooking [5]. Less than $13.9 \%$ of Katanga slum households have access to piped water. Other water sources include boreholes, open wells, few protected springs and streams which are threatened by heavy pollution associated with poor sewage disposal and lack of toilets [10].

\section{Slum Settlement Policies in Uganda}

Every government is responsible for executing appropriate policies to enable formal settlements, equitable distribution of resources and sustainable urban growth. Ideally, cities are economic as well as social focal points of developed societies. However, an all-inclusive approach in relation to planning and management of cities is paramount in improving the livelihood of dwellers [1]. Therefore, viable urbanization necessitates that cities be able to create sustainable income and employment opportunities, sustain good infrastructure, clean water, sanitation, energy, information and communication. Advocating policies that support formal settlements, equitable distribution and accessibility of services, lessen the number of slums dwellers while heightening the ability to conserve natural resources around and within the city.

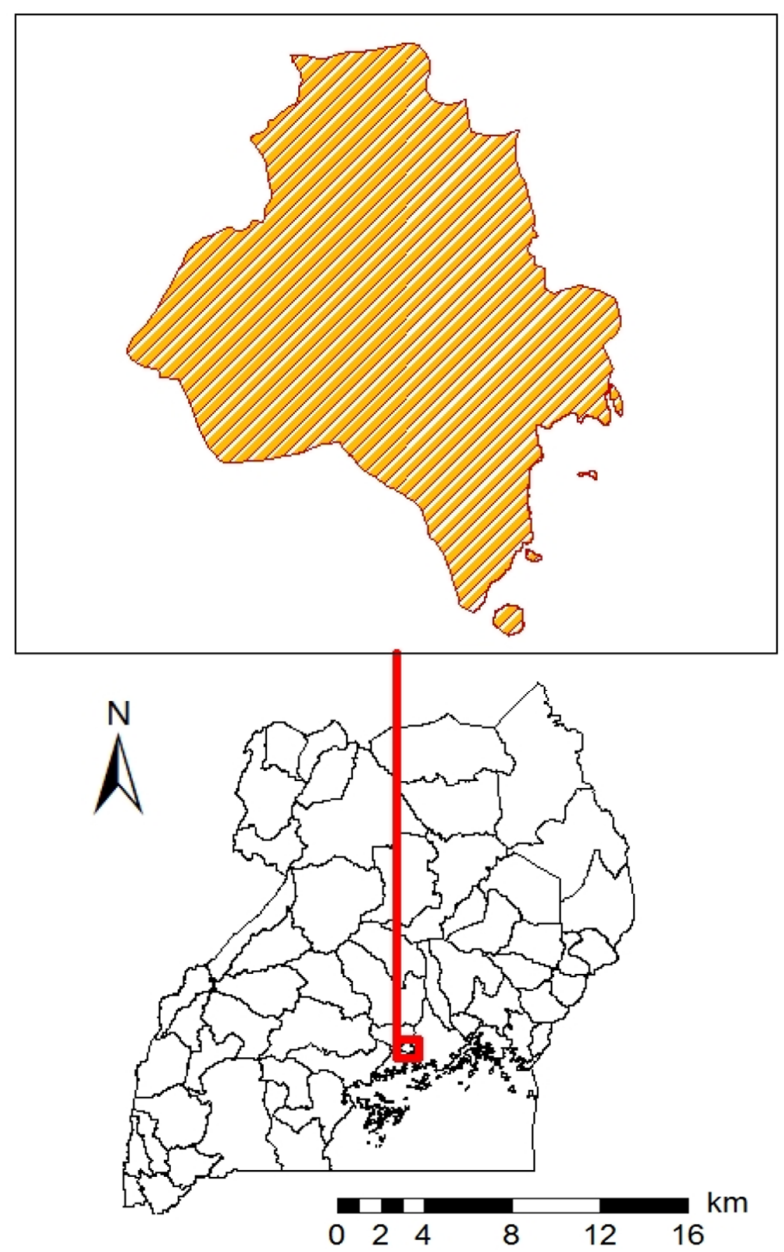

\section{Legend}

VIIIIA uganda_districts97_Clip

Fig. 1. Map of Kampala City, Uganda.

The Ugandan parliament developed UNSUS and Action Plan in 2008 to uplift livelihoods of about one million slum dwellers by 2020 [10]. It was developed to provide a framework, direction and plan to all stakeholders: government, urban authorities, NGOs and Community Based Organizations [5]. However, implementation of these strategies is still challenging.

\section{Integrate Biogas Digester, Poultry and Backyard Gardening Project}

It is estimated that $68 \%$ of Africa's population live without clean cooking facilities and energy despite the high rates of urbanization [11]. Energy access plays a key role in poverty alleviation especially where people live under extreme poverty and use wood based fuels. Forest depletion is inevitable if households continue using firewood for cooking purposes. The current climate change trends 
necessitates adoption of technologies and solutions that can address these problems. The biogas, poultry and backyard gardening project can have a combined solution that simultaneously curbs problems of fuel scarcity, food insecurity and poor health and addressing land degradation. The project will provide energy from biogas digester and concurrently the poultry reared and the backyard garden products will have positive impacts on nutrition and food security of slum dwellers.

\subsection{Project Description}

\subsubsection{Site survey}

To eliminate problems arising from poor planning, site survey for a biogas plant project is very crucial. First, the ministry of lands, housing and urban development and Kampala Capital City Authority together with the local council must be informed accordingly. Consequently, a thorough inspection of the type of feedstocks, household sizes, available usable space, and types of structures among others is done. For Katanga slums, status assessment of available toilets, space for building new structures and poultry houses plus small space for gardening will be done. A technical master plan survey of the biogas plants will then be outlined within designated areas. The residents will be sensitized accordingly via focused group discussions on the intended benefits of the entire project. Similarly, necessary collaborations and participation strategies with the slum dwellers will be underscored earlier enough to avoid future resistance. Necessary training and education on construction skills will be conducted to the slum dwellers as a way of heightening their participation and involvement in the project [12]. A service delivery model intended for Katanga slum integrated project is illustrated by Fig. 2.

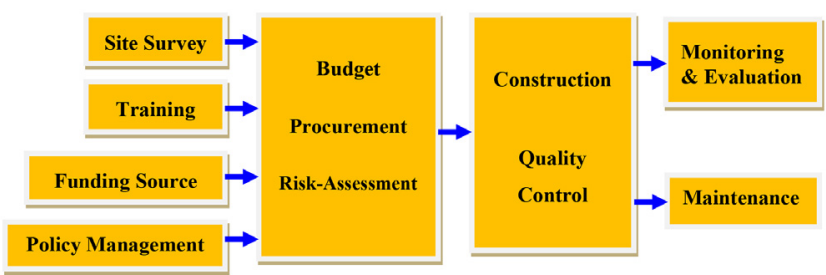

Fig. 2. Functional delivery model for Katanga integrated project.

\subsubsection{Prerequisite preparations for the project}

Upon sorting the preliminary requirements, source of funding and proper initial site preparations will commence. With funds allocated, all the necessary tools and equipment required for the entire project will be bought. This will be allocated according to the budgeted amounts for the entire project (Table 2). A sizable poultry house measuring $2 \mathrm{~m}$ by $3 \mathrm{~m}$ with a cage capacity for maximum 20 hens will be constructed. The floor should be cemented and cage partitions put with wire mesh for channeling droppings into collection trays. The collected chicken droppings are then transferred to a mixing chamber before feeding them into the digester. Similarly, toilets constructed to serve approximately 30 households are built and connected via a pipe to a single digester tank. Consequently, land preparations as well as hanging gardens are prepared in readiness for transplanting vegetables and fruits seedlings from seed beds. Fig. 3 gives the overall outline of the biogas cum poultry and garden project plan.

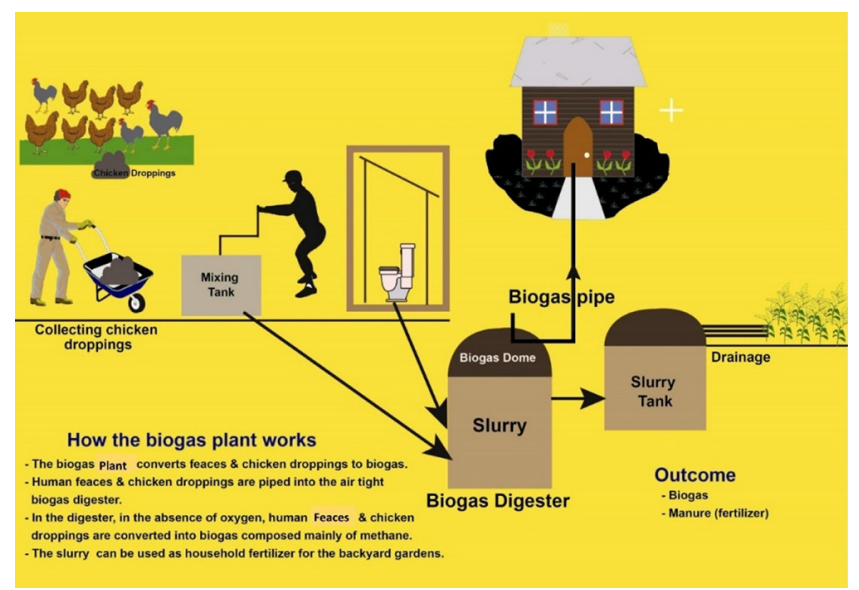

Fig. 3. Feedstock digestion process and products.

\subsubsection{Biogas digester design layout}

A fixed dome domestic biogas digester model useful for family set up was chosen. According to Sasse et al. [12], fixed dome model is preferable because of its longer lifespan of more than 20 years. It is easy to operate and not easily damaged since it is underground. A sizable digester of volume $15 \mathrm{~m}^{3}$ is chosen depending on the approximated amounts of wastes that should result from toilets and poultry houses (Table 1) [13]. Combination of human and poultry feaces is projected to give better biogas yields and therefore could be viable in the long run [14]. Sizing a digester depends on various factors such as waste quantity $\left(V_{\text {waste }}\right)$, water volume $\left(V_{\text {water }}\right)$, retention time (RT), temperature (T) and acidity $(\mathrm{pH})$ [15]. Therefore, the digester volume size according to the quantity of waste and retention time would be calculated using Eq. (1):

Table 1. Excretes Production Rate - Animals Versus Biogas Yield Potential

\begin{tabular}{ccc}
\hline Livestock & $\begin{array}{c}\text { Dung production } \\
\text { (kg/100 } \mathbf{~ k g ~ o f ~} \text { animal/d) }\end{array}$ & $\begin{array}{c}\text { Biogas potential } \\
\text { (litre of biogas/ } \mathbf{k g} \text { of fresh dung) }\end{array}$ \\
\hline Cattle & 8 & 35 \\
Pig & 4 & 51 \\
Goat & 4 & 35 \\
Poultry hen & 0.12 & 55 \\
\hline
\end{tabular}

Source: Sasse et al. [12] and Twidell \& Weir [13] 
Table 2. Katanga Slum Integrated Project Proposed Budget As at 20th July 2016

\begin{tabular}{|c|c|c|c|c|c|}
\hline Particulars & No & Item & Units & Unit cost (USD) & Amount (USD) \\
\hline \multirow[t]{8}{*}{ Toilets, mixing tanks and digester } & 1 & Bricks & 1,500 & 0.1 & 150 \\
\hline & 2 & Cement & 10 bags & 10 & 100 \\
\hline & 3 & Iron sheets & 5 sheets & 10 & 50 \\
\hline & 4 & Timber & 6 & 2 & 12 \\
\hline & 5 & Nails & $2 \mathrm{~kg}$ & 1 & 2 \\
\hline & 6 & Sand & 1 trip & 100 & 100 \\
\hline & 7 & Aggregate stones & 1 trip & 150 & 150 \\
\hline & 8 & Labour & 2 workers & 200 & 400 \\
\hline \multirow[t]{2}{*}{ Backyard garden } & 9 & Sacks & 10 & 0.2 & 2 \\
\hline & 10 & Labour & 1 & 10 & 10 \\
\hline \multirow[t]{8}{*}{ Poultry houses for 20 hens } & 11 & Bricks & 200 & 0.1 & 20 \\
\hline & 12 & Nails & $1 \mathrm{~kg}$ & 1 & 1 \\
\hline & 13 & Timber & 2 & 2 & 4 \\
\hline & 14 & Wire mesh & 2 roll & 4 & 8 \\
\hline & 15 & Iron sheets & 6 & 10 & 60 \\
\hline & 15 & Chicks & 20 & 0.5 & 10 \\
\hline & 16 & Miscellaneous & 1 & 200 & 200 \\
\hline & \multicolumn{4}{|c|}{ Total } & 1,279 \\
\hline
\end{tabular}
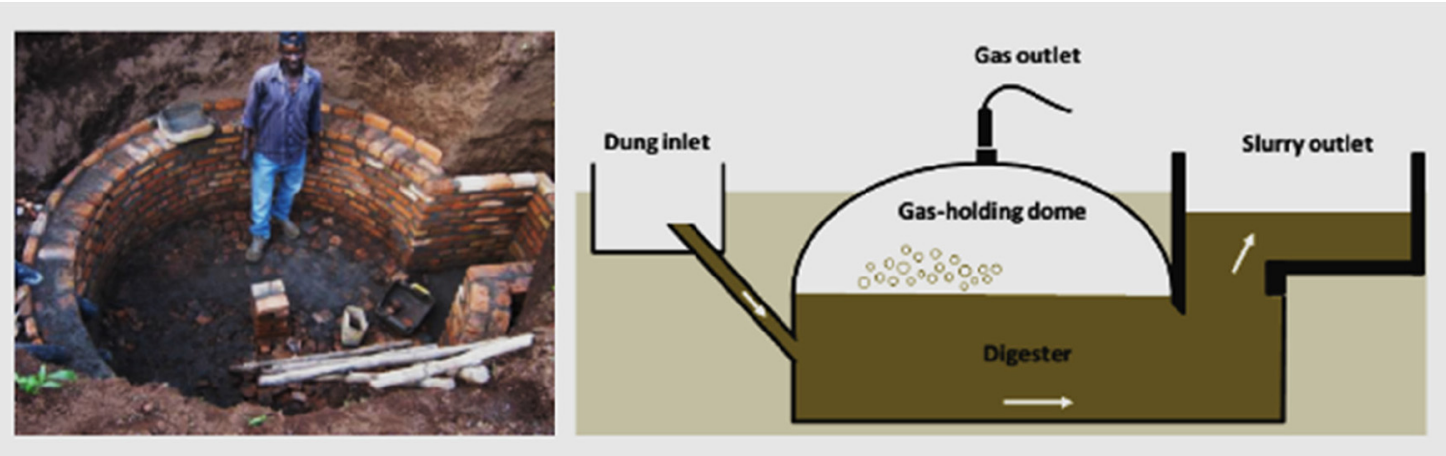

Fig. 4. Fixed dome technology. Source: Sasse et al. [12].

$$
\text { Volume }_{\text {digester }}=\frac{R T \times\left(V_{\text {waste }}+V_{\text {water }}\right)}{1-x}
$$

Where $x$ is the ratio of gas volume within the digester and it's volume. For dome digesters, a typical value of $x$ is 0.25 since gas volume in the dome usually represents around $25 \%$ of the total digester volume. The retention time should be $30 \mathrm{~d}$ subject to digester temperature range which is designed to be between $15-30^{\circ} \mathrm{C}$. Similarly, solid wastes to water ratio should be $1: 1$ while the ideal $\mathrm{pH}$ level chosen for a fixed dome disgeter is 7 [16].

\subsubsection{Construction}

This is carried out using locally acquired materials according to the design considerations and standards. The mixing chamber section for both the toilet and poultry wastes is lined with the digester inlet so as to enable proper mixing and water addition before being fed. Similarly, a secondary digester is constructed to act as a surging tank especially during rainy seasons providing safety to the main digester. Fig. 4 illustrates a typical construction site and picture of a fixed dome digester.

\subsubsection{Biogas and slurry units}

One fixed dome digester will supply 30 households with biogas for cooking and lighting meeting their energy demands. Biogas yielded will then be channeled via gas piping system to households. Consequently, slurry from the digester will be collected and dried before using the as fertilizers to the backyard gardens.

\subsubsection{Operations and maintenance}

The fixed dome biogas digester is easy to maintain since no specialized personnel is needed to operate it. Katanga slum dwellers will be trained and given the responsibility of routine maintenance. 
Normally, a fixed dome digester takes over $20 \mathrm{y}$ to get damaged [17]. Each household will be responsible for collecting and bringing chicken droppings to the digester daily while human feaces will be channeled automatically into the digester. For equitable distribution of the biogas and slurry yielded a person will be in charge.

\subsection{Why Combine Three Ventures under One Project?}

To maximize the potential of slum settlements, the project will ensure that wastes from households become very useful in improving the livelihood of slum dwellers. According to Bill \& Melinda Gates [7], chicken and small livestock projects have the potential of combating poverty in areas with limited space for expansion. Similarly, they can empower women thereby improving overall health conditions of people and development in areas where poverty is still a serious challenge. Nansubuga et al. [13] noted that human feacal matter mixed together with poultry droppings produce more and good quality biogas compared to animal or human feacal matter alone. Consequently, slurry from biogas digesters will be used by every household to generate substantial amount of vegetables that can immensely reduce their cost of living. Comparatively, Warnars \& Hivos [18] indicated that slurry from digesters used in backyard gardens has potential of improving yields by about $10-50 \%$ unlike compost manure alone.

Vitally, this project strives to address problems of water and land pollution that cause degradation when wastes are not handled properly. For single biogas plant or poultry project, bio-slurry and poultry droppings can end up polluting land and water bodies. Similarly, backyard gardening project alone would be unviable without bio-slurry and poultry droppings thus low vegetable yields. Therefore, the three ventures under one project boost the efficiency and output of each individual project. Finally, the project endeavor to significantly impact the social, environmental and economic aspects of Katanga slum community.

\section{Project Impacts}

The Katanga slum biogas, poultry and gardening project has threefold potential impacts (Fig. 5).

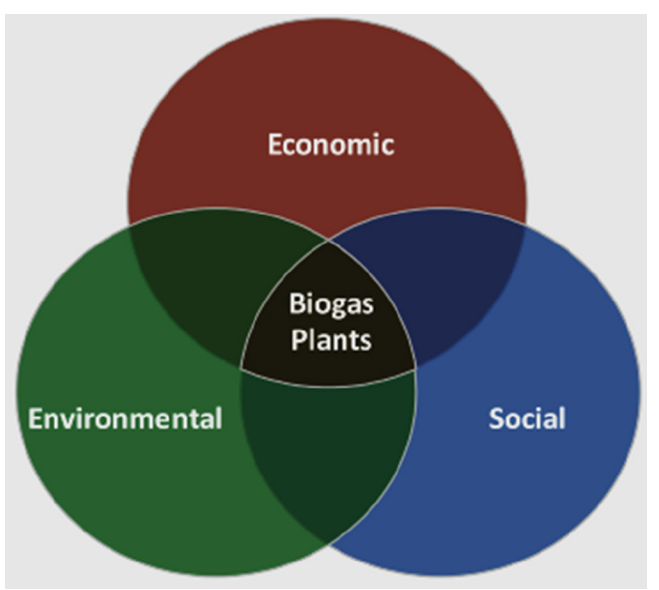

Fig. 5. Integrated project triple win plan. Source: Rakotojaona [16].

\subsection{Environmental Impacts}

This project has potential of reducing the prevalent biomass resource depletion. This is true since households that mainly use firewood and charcoal for cooking and heating, would use biogas thereby vastly curbing the problem of deforestation. Similarly, this project will aid in reduction of greenhouse gas (GHG) emissions [19-21]. The use of unsustainable wood for heating and cooking results in positive GHG emissions, whereas biogas provides clean energy with minimal pollution. Again, pollution caused by open defecation will be greatly reduced because of the permanent toilets. The biogas plant project can substitute the use of firewood and charcoal in slum settlements thus saving the environment in the long run [19]. Slurry from biogas digesters used in backyard gardens will significantly reduce the rate of water and land degradation as compared to inorganic fertilizers [20-21].

\subsection{Social Impacts}

This project aims at improving quality of life of the vulnerable slum dwellers especially women and children. Biogas cooking is more convenient and faster than firewood and charcoal stoves. With this improved cooking system, families will cook cleaner and hygienic foods [22]. Similarly, this project will promote gender equality by empowering women and children who are predominantly involved in house chores. Though men are the breadwinners, Katanga slum women are largely jobless and thus can hardly sustain their households. Therefore, providing improved fuel for cooking, clean sanitation and improved gardens will result in emancipation. Women are generally hard working thus this breakthrough will stop overdependence of women on their husbands for family needs. This will strike a balance in families especially where men are irresponsible drunkards as in Katanga slums.

Alternatively, this project will greatly improve the health and sanitation status of the Katanga slum dwellers. Currently, cooking with firewood and charcoal has led to indoor pollution which poses great health risks as respiratory diseases [23]. However, biogas cooking has minimal indoor pollution since bio-digesters are known to reduce pathogenic content of organic materials vastly [21]. Consequently, this enhanced sanitation of households and improved food supply will directly boost the health status of children and adults in Katanga slum.

Finally, this project will have great impact on education performance of children within the Katanga slum. Biogas lamps fixed in every house will provide lighting for school children to conduct their studies at night. Biogas lamps produce high quality light compared to kerosene lamps that are commonly used in Katanga slum [24].

\subsection{Economic Impacts}

According to Katuwal and Bohara [21], proper implementation of biogas project has eminent benefits to a community. Consequently, this project will significantly reduce expenses incurred by households for fuel, food, and vegetables thereby impacting their income status which is majorly below one dollar per day [22]. Bio-slurry to improve the backyard garden yields will be a great relief to Katanga slum dwellers since inorganic fertilizers are very exorbitant to acquire. Moreover, this threefold project 
has the potential of stimulating national economy by creating jobs, increasing food production and improving health and sanitation status of slum settlements [24].

\section{Proposed Budget}

The optimum budget needed for the whole project is approximated as USD 1,279 (Table 2). However, approximately $30 \%$ of the budget including building materials and labour will be contributed by the local people while the remaining $70 \%$ will be sourced externally. The budget includes all materials needed to construct poultry houses, toilets, mixing tanks, digesters and backyard gardens. The initial cost for implementing this project is affordable yet the projected social, economic and environmental impacts are immeasurable.

\section{Expected Outcomes}

Successful implementation of the project will induce establishment of decentralised energy information centres to give locally appropriate advice to other slum settlements and various authorities. Furthermore it will enhance community involvement on informed decision making regarding project utilisation, capacity building and access to information. Katanga slum residents will be empowered on the need to spearhead the area's economic, social and infrastructural growth as a way of improving development and quality life [24].

A bridge for food and nutritional security providing micronutrients from fruits and vegetables will greatly improve maternal and child health. Again, improved sanitation will minimise morbidity and mortality rates resulting from poor sewage disposal. Promoting access to proper waste management systems and clean water will curb waterborne diseases. Finally, this project will create employment opportunities and in turn reduce incidences of crime and insecurity within Katanga slum.

\section{Conclusions}

The integrated triple win project is a sustainable venture in providing energy for lighting and cooking for slum dwellers. Poultry rearing and backyard gardening are sources of food and revenue that can sustain households enhancing their social and health wellbeing. Adopting this pilot project in Katanga slum will enhance diversified benefits to households and serve as example to national strategists. The benefits of utilizing wastes produced within the slum settlements to uplift infrastructural, socio-economic and health standards are key. Therefore, this project proposal offers viable answers to nearly all the bottlenecks of urbanization and thus should be adopted accordingly.

\section{References}

1. United Nations, Department of Economic and Social Affairs,
Population Division. World Urbanization Prospects: Economic \& Social Affairs. New York; 2014. p. 1-32. [cited 30 September 2016]. Available from: https://esa.un.org/unpd/wup/publications/ files/wup2014-highlights.pdf.

2. Nsiah-Gyabaah K. Urbanization, environmental degradation and food security in Africa. The Global Environmental Change research community, Nontreal, Cananda. Sunyani, Brong Ahafo. Ghana; 2003. p. 16-18. [cited 7 November 2016]. Available from: https://www.sedac.ciesin.columbia.edu/openmtg/ docs/Nsiah-Gyabaah.pdf.

3. Uganda Bureau of Statistics. National population and housing census 2014 provisional results. Revised edition, November, 2014. [cited 23 June 2016]. Available from: www.ubos.org//.

4. Kiyaga-nsubuga J, Magyezi R, Brien SO, Sheldrake M. Hope for the urban poor: DFID city community challenge (C3) fund pilot in Kampala and Jinja, Uganda. Environ Urban. 2001;13: 115-124.

5. Government of Uganda. National slum upgrading strategy and action plan. Kampala, Uganda; 2008. [Cited 14 October 2016]. Available from: http://ssauganda.org/uploads/national\%20slum\% 20upgrading\%20strategy\%20ug\%20(2).pdf.

6. Zuzhang X. Domestic biogas in a changing China: Can biogas still meet the energy needs of China's rural households? In: Rogers C, ed. London: International Institute for Environment and Development (UK); 2013. p. 1-40.

7. Gates B, Gates M. Why I would raise Chiken [Internet]. c2016. Available from: https://www.gatesnotes.com/Development/Why-IWould-Raise-Chickens?WT.mc_id=20160609120700_CoopDr eams BG-TW\&WT.tsrc $=$ BGTW\&linkId $=25357346$.

8. Food and Agriculture Organization of the United Nations, 2014. [cited 21 July 2014]. Available from: http://www.ftp.fao.org/3/a-i3556e.pdf.

9. Kruk IM. Slum mapping as a tool for improving the life of slum communities in Africa: Comparative studies of cases from Kenya, Uganda and Namibia [dissertation]. Denmark: Aalborg Univ.; 2015.

10. John Paul II Justice and Peace Centre. Living in Kampala Slums. A socio-economic analysis in then informal settlements of Kampala [Internet]. c2011. [cited 9 November 2016]. Available from: http://www.jp2jpc.org/activities/research/.

11. Freire ME, Lall S, Leipziger D. Africa's urbanization: Challenges and opportunities [Internet]. Washington D.C. 20052; 2014. Report No.: 7. Available from: www.growthdialogue.org.

12. Sasse L, Kellner C, Kimaro A. Improved biogas unit for developing countries. Lengerich, Germany: Friedr. Vieweg \& Sohn Verlagsgesellschaft mbH, Braunschweig; 1991. p. 4-64.

13. Twidell J, Weir T. Renewable energy resources. 2nd ed. London and Newyork: Taylor and Francis Group; 2006. p. 379-389.

14. Nansubuga I, Banadda N, Babu M, Vrieze J De, Verstraete W, Rabaey K. Enhancement of biogas potential of primary sludge by co-digestion with cow manure and brewery sludge. Int. J. Agric. Bol. Eng. 2015;8:86-94.

15, Wang Z, Chen S, Frear C, Kruger C, Granatstein D. Advanced small-scale anaerobic digester design tailored for household user living in cold climate. Washington State University Invention Disclosure: Center for Sustaining Agriculture and Natural Resources; 2009. p. 1-30. 
16. Rakotojaona L. Domestic biogas development in developing countries: A methodological guide for domestic biogas project holders in the early stages of setting up projects in developing countries. Mountain View, California, 94041,USA.: ENEA Consulting; 2013. p. 1-25.

17. Poeschl M, Ward S, Owende P. Environmental impacts of biogas deployment - Part II: Life cycle assessment of multiple production and utilization pathways. J. Clean. Prod. 2012;24: 184-201.

18. Warnars LME, Hivos. Bioslurry: A supreme fertiliser positive effects of bioslurry on crops. Practitioners' Track, IFOAM Organic World Congress 2014, 'Building Organic Bridges'. 2014. p. 13-15.

19. Esfandiari S, Khosrokhavar R, Masih S. Greenhouse gas emissions reduction through a biogas plant: A case study of waste management systems at FEKA dairy farm. 2011 2nd International Conference on Environmental Science and Technology. 2011;6:445-448.
20. Poeschl M, Ward S, Owende P. Environmental impacts of biogas deployment - Part I: Life cycle inventory for evaluation of production process emissions to air. J. Clean. Prod. 2012;24: 168-183.

21. Katuwal H, Bohara AK. Biogas: A promising renewable technology and its impact on rural households in Nepal. Renew. Sust. Energ. Rev. 2009;13:2668-2674.

22. Hamlin A. Assesment of social and economic impacts of biogas digesters in rural Kenya. SIT digital collections: Independent study project (ISP) collection [dissertation]. New York: Univ. of Rochester, SIT Graduate Institute; 2012.

23. Stoyanov T. Socioeconomic impacts from the implementation of biogas production in Bulgaria [dissertation]. Denmark: Aalborg University; 2013.

24. Kanagawa M, Nakata T. Analysis of the energy access improvement and its socio-economic impacts in rural areas of developing countries. Ecol. Econ. 2007;62:319-329. 